\title{
PEMANFAATAN BAKTERI BACILLUS DENGAN TRICHODERMA UNTUK PENINGKATAN PRODUKSI TANAMAN BAWANG MERAH DALAM PEMBERDAYAAN KELOMPOK TANI PADANG LAWEH NAGARI SUNGAI NANAM KABUPATEN SOLOK
}

\author{
Yulmira Yanti ${ }^{1 *}$, Hasmiandy Hamid ${ }^{1}$, Noveriza Hermeria ${ }^{2}$ \\ 1) Program Studi Proteksi Tanaman Fakultas Pertanian Universitas Andalas Padang 25163 \\ 2) Mahasiswa Program Studi Proteksi Tanaman Fakultas Pertanian Universitas Andalas Padang 25163 \\ "Email:mira23@gr.unand.ac.id; yy.anthie79@gmail.com
}

\begin{abstract}
ABSTRAK
Nagari Sungai Nanam merupakan salah satu nagari di Kecamatan Lembah Gumanti, Kabupaten Solok dengan pertanian sebagai sektor ekonomi utama yaitu budidaya tanaman bawang merah. Tanaman bawang merah memiliki potensi pengembangan yang sangat baik. Permintaan pasar akan komoditi tanaman bawang merah cenderung meningkat setiap tahunnya berkaitan dengan pertumbuhan jumlah penduduk. Tujuan dari kegiatan pemberdayaan kelompok tani ini adalah untuk memberikan pengetahuan dan juga informasi megenai cara peningkatan produksi tanaman bawang merah nagari sungai nanam dengan cara yang efektif dan efisien melalui pemanfaatan bakteri Bacillus spp dan Trichoderma spp. Metode pelaksanaan kegiatan meliputi survei pendahuluan pendekatan sosial, penyuluhan, pelatihan dan pembuatan demplot. Kegiatan ini sangat bermanfaat bagi masyarakat khususnya kelompok tani Padang Laweh, Nagari Sungai Nanam. Antusias dan partisipasi masyarakat sangat menunjuang keberhasilan dalam kegiatan ini. Pertumbuhan dan hasil produksi terbaik di dapatkan pada perlakuan dengan penggunaan bakteri Bacillus spp. Dalam penerapan teknologi menggunakan bakteri Bacillus spp dan Trichoderma spp ini sangat membantu percepatan pertumbuhan tanaman bawang merah dibandingkan dengan yang biasa ditanam masyarakat tanpa menggunakan perlakuan. Penggunaan bakteri Bacillus spp ini sangat disarankan karena selain mudah untuk di dapatkan juga memberikan nilai yang positif terhadap pertumbuhan tanaman dan baik untuk lingkungan sekitar tanaman budidaya.
\end{abstract}

Kata kunci: Bawang merah, Bakteri Bacillus, Trichoderma, Pemberdayaan

\section{PENDAHULUAN}

Kelompok tani Padang Laweh jorong Padang Laweh Nagari Sungai Nanam merupakan salah satu kelompok tani di Kecamatan Lembah Gumanti dengan sektor utama budidaya pertanian. Kelompok tani Padan Laweh biasanya hanya membudidayakan berbagai tanaman hortikultura dengan akses ke ibu kota provinsi dan kabupaten yang cukup jauh menjadi salah satu kendala pertumbuhan ekonomi daerah tersebut. Hal ini menyebabkan keterbatasan sarana produksi seperti pupuk yang tidak tersedia sesuai kebutuhan masyarakat. Sering terjadi kelangkaan pupuk karena pupuk subsidi hilang di pasaran, sehingga petani sulit untuk mempertahankan produksinya. Akhirakhir ini pupuk subsidi tidak dapat memenuhi kebutuhan petani akan pupuk. Apalagi ditambah rencana pemerintah untuk mengurangi/menghapus subsidi pupuk secara bertahap, maka petani akan kesulitan untuk memenuhi kebutuhan pupuknya. Untuk mengendalikan hama dan penyakit, petani di daerah ini juga rutin menggunakan pestisida sintetis Teknologi Tepat Guna 170 
seperti insektisida, fungisida dan bakterisida. Biaya yang dikeluarkan untuk pembelian pestisida mencapai $50 \%$ dari biaya produksi.

Bawang merah (Allium ascalonicum) merupakan salah satu komoditas pertanian yang banyak dikonsumsi oleh masyarakat Indonesia sebagai bumbu masakan. Permintaan masyarakat Indonesia terhadap bawang merah dalam kurun waktu tahun 2007 hingga tahun 2010 mengalami peningkatan dari 901102 ton menjadi 1116275 ton (KEMENTAN 2015), yang diikuti oleh peningkatan produksi bawang merah dari 802827 ton menjadi 1 046325 ton (BPS 2015). Meskipun begitu, peningkatan produksi bawang merah belum mampu mengimbangi peningkatan permintaan masyarakat. Sebagai komoditas hortikultura yang banyak dikonsumsi masyarakat, potensi pengembangan bawang merah masih terbuka lebar tidak saja untuk kebutuhan dalam negeri tetapi juga luar negeri (Suriani, 2011).

Salah satu kendala dalam produksi bawang merah yaitu adanya serangan OPT (Organisme Pengganggu Tanaman). Potensi kehilangan hasil oleh OPT pada stadia tanaman tua dan muda dapat mencapai 20-100\% tergantung pengelolaan budidaya bawang merah (Adiyoga et al., 2001). Pada saat ini upaya pengendalian terhadap penyakit tanaman masih mengandalkan penggunaan pestisida sintetik. Upaya pengendalian dengan menggunakan pestisida sintetik bukan merupakan alternatif yang terbaik untuk melindungi tanaman dari kerusakan penyakit tanaman. Penggunaan pestisida secara berlebihan dapat menimbulkan dampak negatif misalnya dapat memicu timbulnya patogen yang resistensi, pencemaran lingkungan, musnah nya musuh alami, timbulnya residu pestisida, ancaman terhadap kualitas lingkungan, keseimbangan ekosistem maupun kesehatan manusia. Oleh karena itu perlu strategi pengendalian yang tepat dan efektif dan juga aman terhadap lingkungan dan kesehatan manusia dengan menggunakan agen hayati (Yanti et al., 2019).

Teknologi yang sedang pesat perkembangannya saat ini adalah pemanfaatan mikro organisme (bakteri saprofit non patogenik) yang di eksplorasi dari rizosfer tanaman (rizobakteri) yang dapat memacu pertumbuhan tanaman (Loon, 2007). Rizobakteri memiliki kemampuan mengkolonisasi rizosfer secara agresif dan beberapa jenis rizobakteri mampu berperan ganda sebagai biofertilizer dan bioprotektan pada tanaman (Ashrafuzzaman et al., 2009). Penelitian mengenai pengendalian penyakit pada tanaman bawang merah sudah banyak dilakukan oleh penulis dan telah banyak dipublikasi. Isolat bakteri rizoplan indigenus yang diperoleh terbukti mampu mengendalikan penyakit awar daun bakteri pada tanaman bawang merah (Yanti et al., 2010; 2011), serta memiliki kemampuan dalam menginduksi aktifnya enzim pertahanan pada tanaman bawang merah (Yanti et al., 2011;2015).

Penggunaan Trichoderma di samping sebagai organisme pengurai, dapat pula berfungsi sebagai agen hayati dan stimulator pertumbuhan tanaman. Beberapa spesies Trichoderma telah dilaporkan sebagai agensia hayati seperti $T$. harzianum, $T$. viridae, dan $T$. konigii yang berspektrum luas pada berbagai tanaman pertanian.

Teknologi Tepat Guna 171 
Biakan jamur Trichoderma diberikan ke areal per tanaman dan berlaku sebagai biodekomposer, mendekomposisi limbah organik menjadi kompos yang bermutu. Serta dapat berlaku sebagai biofungisida, yang berperan mengendalikan organisme pathogen penyebab penyakit tanaman. Trichoderma dapat menghambat pertumbuhan beberapa jamur penyebab penyakit pada tanaman antara lain Rigidiforus lignosus, Fusarium oxysporum, Rizoctonia solani, Sclerotium rolfsi. Disamping kemampuan sebagai pengendali hayati, T. harzianum memberikan pengaruh positif terhadap perakaran tanaman, pertumbuhan tanaman, hasil produksi tanaman (Avila et al., 2006). Pengenalan sistem budidaya dengan teknologi penggunaan bakteri dari genus Bacillus dan Trichoderma merupakan salah satu alternatif potensial dalam meningkatkan pertumbuhan, hasil serta dalam pengendalian OPT bawang merah. Untuk itu, pengenalan teknologi ini bagi kelompok tani Padang Laweh diharapkan mampu meningkatkan produksi bawang merah dan menurunkan biaya produksi dari segi penggunaan pupuk dan pestisida sintetis. Berdasarkan permasalahan di atas dan dari hasil penelitianpenelitian sebelum yang dilakukan oleh tim pelaksana kegiatan telah didapatkan beberapa agen sia hayati yang telah di formulasi dengan menggunakan bahan berupa limbah air kelapa, molases dan ampas tebu. Agensia hayati dapat digunakan sebagai pengganti pestisida sintetis untuk pengelolaan beberapa hama dan penyakit penting yang sering menyerang tanaman bawang merah petani di daerah ini. Adapun tujuan dari kegiatan pengabdian masyarakat ini ialah meningkatkan produksi tanaman bawang merah dan pendapatan kelompok tani Padang Laweh dengan cara yang efektif dan efisien melalui penggunaan Bacillus dan Trichoderma.

\section{METODE}

Program pengabdian masyarakat ini diadakan pada bulan Maret 2021 dengan lokasi kegiatan di kelompok tani Padang Laweh Jorong Padang Laweh, Nagari Sungai Nanam, Kecamatan Lembah Gumanti, Kabupaten Solok, Sumatera Barat. Peserta kegiatan ini ialah masyarakat kelompok tani Padang Laweh jorong Padang Laweh.

\section{A. Survei Pendahuluan dan Pendekatan Sosial}

Tahap ini bertujuan untuk melakukan komunikasi dan sosialisasi tujuan pra-kegiatan dengan perwakilan ketua kelompok tani dan perangkat Nagari (Desa). Dari kegiatan ini diharapkan adanya kerjasama antara masyarakat, unit pengelola penyuluhan berbasis petani dan aparat pemrintah serta memperoleh legitimasi dan dukungan bagi semua kegiatan yang berkaitan dengan pelaksanaan pengabdian. Masyarakat juga diharapkan dapat bersedia untuk mengikuti kegiatan ini serta menyedakan waktu dan lahan percontohan.

\section{B. Penyuluhan}

Kegiatan ini bertujuan untuk memberikan materi penyuluhan berupa: 
a. Hama dan penyakit utama pada budidaya tanaman bawang merah

b. Dampak negatif penggunaan pestisida sintetik yang intensif dan tidak bijaksana dalam pengendalian hama dan penyakit

c. Pemanfaatan agens hayati Bacillus dan Trichoderma dalam pengendalian hama dan penyakit tanaman bawang merah

\section{Pelatihan}

Pelatihan yang dilakukan bertujuan untuk menambah wawasan dan pengetahuan petani tentang penggunaan dan pemanfaatan agensia hayati Bacillus dan Trichoderma. Pelatihan ini dilakukan pada semua anggota kelompok tani mitra. Pelatihan yang diberikan bagi anggota kelompok tani yaitu teknik budidaya bawang merah sehat, teknik perbanyakan dan aplikasi agens hayati Bacillus dan Trichoderma

\section{Pembuatan Demplot}

Pembuatan demplot bertujuan untuk meyakinkan petani bawang merah tentang kemampuan agensia hayati Bacillus dan Trichoderma dalam mengendalikan hama dan penyakit pada tanaman bawng merah secara nyata dan langusung. Demplot percontohan dilaksanakan di salah satu lahan milik anggota kelompok tani. Agensia hayati yang digunakan dikembangkan di laboratorium Mikrobiologi dan Fitopatologi Jurusan Hama dan Penyakit Tumbuhan (HPT) Fakultas Pertanian, Universitas Andalas, Padang. Aplikasi agensia hayati Bacillus dilakukan mulai dari seed treatment (perlakuan benih) bawang merah sebelum tanam sampai tanaman berbuah/sia panen dengan interval 1 minggu sekali. Aplikasi agens hayati Trichoderma dilakukan dengan aplikasi soil treatment saat pengolahan tanah terakhir. Masing-masing kelompok tani bertanggung jawab dalam melakukan pemeliharaan, pemantauan sampai panen.

\section{HASIL DAN PEMBAHASAN}

\section{A. Survei Pendahuluan dan Pendekatan Sosial}

Sebelum melaksanakan pengabdian, tim pengabdian Fakultas Pertanian melakukan survei dengan mengunjungi lokasi pengabdian dan melakukan wawancara bersama Wali Nagari Sungai Nanam sebagai lokasi terpilih untuk pelaksanaan program Pengabdian Kepada Masyarakat pada tanggal 7 Maret 2021 (Gambar 1). Berdasarkan hasil diskusi dan penjajakan awal, permasalahan budidaya tanaman di Nagari ini dijadikan sebagai bahan pertimbangan untuk melakukan pengabdian. Berdasarkan diskusi, uga dipilih Kelompok Tani mitra di Nagari Sungai Nanam sebagai kelompok tani percontohan kegiatan pengabdian di nagari tersebut yaitu kelompk tani Padang laweh yang biasanya mengusahakan budidaya tanaman hortikultura.

Diskusi selanjutnya dengan kelompok tani mitra didapatkan informasi petani tidak melakukan pergiliran tanaman dalam mengolah lahan pertanian, padahal teknik budidaya tersebut dapat menyebabkan hama dan penyakit tetap berkembang secara kontinu dilapangan. Sebagai alternatif, tim pengabdi mengajukan program budidaya bawang merah dengan memanfaatkan agens hayati sebagai 
salah satu alternatif pengembangan kegiatan produksi pertanian oleh kelompok tani mitra. Kelompo tani mitra memiliki keinginan dan ketertarikan terhadap hal yang demikian. Untuk itu, disampaikan kepada kelompok tani mitra bahwa diperlukan peran aktif bagi tim pengabdi sebagai fasilitator dalam diseminasi teknologi budidaya bawang merah dengan pemanfataan Bacillus dan Trichoderma, keaktifan anggota kelompok tani dalam menerima enyuluhan, pelatihan serta pembuatan demplot serta diskusi aktif tentang kondisi dan permasalahan selama berjalannya program ini.

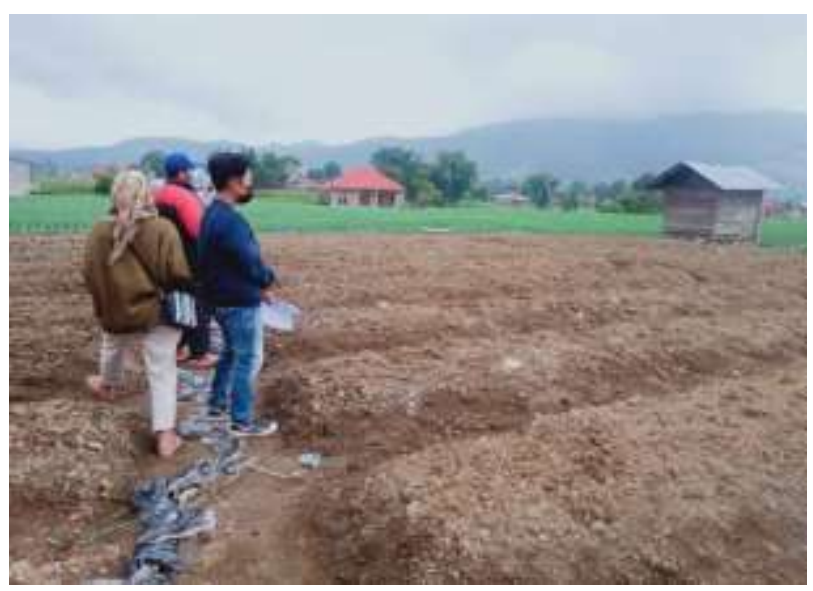

Gambar 1. Survei lokasi yang akan di jadikan demplot percobaan penggunaan agens hayati.

\section{B. Penyuluhan}

Penyuluhan terkait hama dan penyakit tanaman telah dilaksanakan di Kantor Wali Nagari pada 14 Maret yang dihadiri oleh anggota kelompok tani Padang Laweh serta masyarakat Sungai Nanam. Materi utama yang disampaikan dalam kegiatan penyuluhan ini adalah Hama dan Penyakit Pada Tanaman Bawang Merah serta sosialisasi terkait Pengelolaan Hama Terpadu. Berdasarkan diskusi yang dilakukan pada saat kegiatan sosialisasi, petani belum megetahui teknik-teknik pengendalian yang tramah lingkungan karena selama ini hanya berorientasi pada pengunaan pestisida sintetis. Melalui kegiatan penyuluhan ini diharapkan petani dapat memahami perananan teknik pengelolaan hama terpadu. Petani diharapkan dapat melakukan kegiatan pencegaan dengan melakukan berbagai tindakan yang efektif.

\section{Pelatihan}

Pada kegiatan ini, petani dilatih dalam memanfaatkan agens hayati Bacillus dan Trichoderma dalam teknik budidaya tanaman bawang merah. Petani juga diberikan pengetahuan terkait keunggulan dalam penggunaan agens hayati. Pentingnya peran agens hayati dalam mengendalikan hama dan penyakit tanaman bawang merah juga disampaikan kepada kelompok tani. Untuk mempersiapkan agens hayati, petani cukup diberikan penyuluhan dan simulasi pembuatannya di tahap laboratorium.

\section{Demplot Penanaman Bawang Merah}

Demplot penanaman bawang merah berada di lahan salah satu anggota kelompok tani Padang Laweh, tepatnya di jorong Padang Laweh, Nagari Sungai Nanam. Pelaksanaan demplot dilakukan langsung oleh anggota kelompok tani mitra bersama dengan tim pengabdi sebagai fasilitator. Anggota kelompok tani menunjukkan antusiasme yang tinggi terhadap teknik budidaya yang baru yang diperkenalkan oleh tim pengabdi. Lahan yang digunakan adalah lahan yang sebelumnya ditanami dengan tanaman bawang yang belum menggunakan 


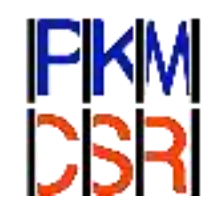

teknik yang disarankan. Lahan diolah dengan membuat bedengan dan ditambahkan dengan pupuk kandang (10 ton/ha) kemudian ditutupi mulsa (Gambar 2). Umbi bawang merah yang digunakan untuk benih adalah sebanyak $80 \mathrm{~kg}$ yang diambil dari hasil panen penanaman sebelumnya. Umbi bawang dipotong 1/3 bagian tas kemudian direndam dengan bakteri Bacillus dan Trichoderma selama 15 menit sebelum ditanam (Gambar 3).

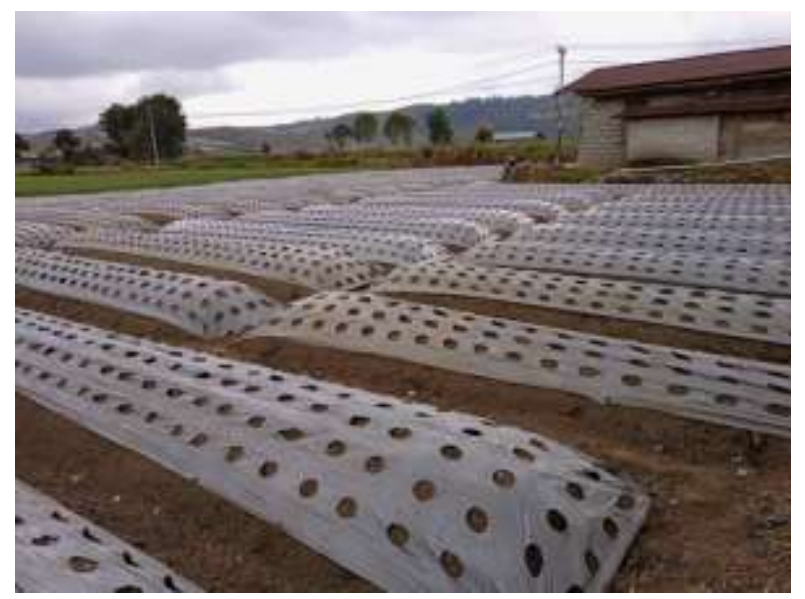

Gambar 2. Pemasangan mulsa d lahan yang akan digunakan sebagai demplot percontohan

Penanaman bawang merah diikuti oleh Tim Pengabdian Masyarakat bersama kelompok tani Padang Laweh. Penanaman dilakukan pada tanggal 21 Maret 2021. Kegiatan pemeliharaan selanjutnya dilakukan oleh kelompok tani mitra yaitu penyiangan gulma yang dilakukan secara mekanik dan dilakukan pencegahan serangan OPT dengan menyemprotkan pestisida nabati yang terbuat dari bahan-bahan alami yang umumnya daunnya memiliki rasa pahit secara rutin (Gambar 4). 


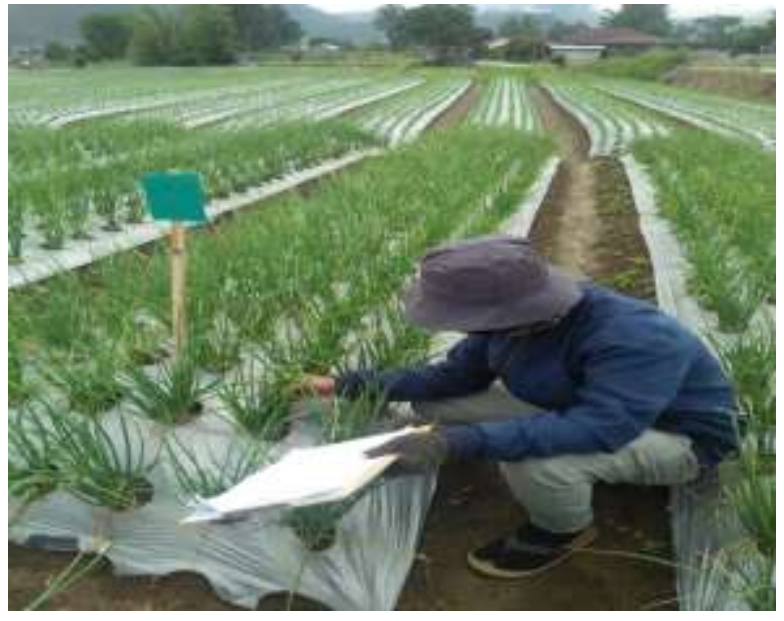

Gambar 5. Tanaman bawang merah umur 42 HST

Hasil pengamatan muncul tunas dan tinggi tanaman dapat dilihat pada (tabel 1). Perlakuan bakteri Bacillus dan Trichoderma mampu meningkatkan pertumbuhan lebih baik dibandingkan dengan kontrol. Perlakuan Bacillus mampu meningkatkan produksi bawang merah dengan meningkatkan berat basah dan berat kering umbi dibandingkan dengan kontrol (Tabel 2).

Tabel 1. Pertumbuhan Bawang Merah

\begin{tabular}{lcc}
\hline Perlakuan & Muncul Tunas & Tingi Tanaman \\
\hline Bacillus & $3,02 \mathrm{a}$ & $38.44 \mathrm{a}$ \\
Trichoderma & $3,33 \mathrm{a}$ & $32,94 \mathrm{~b}$ \\
Kontrol & $5,14 \mathrm{~b}$ & $23,22 \mathrm{c}$ \\
\hline
\end{tabular}

Tabel 2. Produksi bawang merah

\begin{tabular}{llr}
\hline Perlakuan & Berat Basah $(\mathrm{g})$ & Berat Kering $(\mathrm{g})$ \\
\hline Bacillus & $121,75 \mathrm{a}$ & $117,57 \mathrm{a}$ \\
Trichoderma & $111,57 \mathrm{~b}$ & $105,53 \mathrm{~b}$ \\
Kontrol & $39,23 \mathrm{c}$ & $25,23 \mathrm{c}$ \\
\hline
\end{tabular}

Pertumbuhan dan hasil produksi terbaik di dapatkan pada perlakuan dengan penggunaan bakteri Bacillus spp. Hasil kegiatan pengabdian sebelumnya juga telah menunjukkan adanya peningkatan produksi bawang merah dengan pemanfaatan produk rizobakteri Yuyaost dan Trichoderma (Yanti et al., 2018). Peningkatan hasil produksi bawang merah dapat dilihat dan di praktekkan langsung oleh anggota kelompok tani melalui pelaksanaan demplot. Pengaruh aplikasi penggunaan bakteri Bacillus spp ini sangat disarankan karena selain mudah untuk di dapatkan juga memberikan nilai yang positif terhadap pertumbuhan tanaman dan baik untuk lingkungan sekitar tanaman budidaya.

\section{KESIMPULAN}

Kegiatan ini sangat bermanfaat bagi masyarakat khususnya kelompok tani Padang Laweh jorong Padang Laweh, Nagari Sungai Nanam. Antusias dan partisipasi aktif dari masyarakat sangat menunjang keberhasilan dari pelaksanaan kegiatan ini. Pertumbuhan dan hasil produksi yang terbaik didapatkan pada perlakuan menggunakan bakteri Bacillus. Dalam penerapan teknologi menggunakan bakteri Bacillus spp dan Trichoderma spp ini sangat membantu percepatan pertumbuhan tanaman bawang merah dibandingkan dengan yang biasa ditanam masyarakat tanpa menggunakan perlakuan (kontrol). Penggunaan Bacillus ini sangat disarankan karena selain mudah untuk didapatkan juga memberikan nilai positif terhadap pertumbuhan tanaman dan baik untuk teknologi lingkungan sekitar tanaman budidaya. 


\section{DAFTAR PUSTAKA}

Adiyoga, W., Laksanawati, A., Soetiarso, T.A., \& Hidayat, A. (2001). Persepsi petani terhadap status dan prospek penggunaan SeMNPV pada usahatani bawang merah. J Hort. 11(1), 58-70

Ashrafuzzaman M, Hossen FA, Ismail MR, Hoque MA, Islam MZ, Shahidullah SM, and S. Meon. 2009. Efficiency of plant growthpromoting rhizobacteria (PGPR) for the enhancement of rice growth. African $J$. Biotechnol. 8: 1247-1252

Avila, Miranda M.E, Herrera Estrella, A, Pena, and J.J Cabriales. 2006. Colonization of the rhizosphere, rhizoplane and endorhiza of garlic (Allium sativum L.) by strains of Trichoderma harzianum and their capacity to control allium white-rot under field conditions. Soil Biol Biochem 38:18231830

[BPS] Badan Pusat Statistik. (2015). Produktivitas bawang merah 2006-2011. [Internet]. [diunduh 2015 Mei 29]. Tersedia pada: http://www.bps.go.id/site/resultTab.

[KEMENTAN] Kementerian Pertanian. (2015). Konsumsi per kapita dalam rumah tangga setahun menurut hasil Susenas. [Internet]. [Diunduh 2016 Sept 05]. Tersedia pada: https://aplikasi2.pertanian.go.id/ konsumsi/tampil_susenas_kom2_th.php.

Suriani, N. 2011. Bawang Bawa Untung. Budidaya Bawang Merah dan Bawang Merah. Cahaya Atma Pustaka, Yogjakarta.

Van Loon LC. 2007. Plant response to plant growth promoting rhizobacteria. Eur. J. Plant Pathol. 119: 243-254.
Yanti, Y dan Z. Resti. 2010. Induksi ketahanan bawang merah menggunakan bakteri endofit untuk mengendalikan penyakit hawar daun bawang. Prosiding Semirata BKS PTN

Yanti, Y dan Z. Resti. 2011. Induksi ketahanan bawang merang menggunakan rhizobakteria untuk pengendalian penyakit pada bawang merah. prosiding seminar nasional MIPA, Padang

Yanti, Y., Mayerni, R dan Yusniwati. 2015. IbM Pemanfaatan Mikro organisme Lokal Untuk Mengendalikan Hama dan Penyakit Tanaman Bawang Merah Di Nagari Aie Dingin. Laporan Pengabdian kepada Masyarakat 